\title{
Harvesting, processing and quality control of oil radish seeds ${ }^{1}$
}

\author{
Marcela Carlota Nery ${ }^{2 *}$, Maria Laene Moreira de Carvalho ${ }^{3}$, \\ Andréa dos Santos Oliveira ${ }^{3}$, Joelma Pereira ${ }^{3}$, Fernanda Carlota Nery ${ }^{4}$
}

\begin{abstract}
The oil radish siliques maturation occurs in a non-uniform way, which makes it difficult to define the ideal harvesting time in order to produce high quality seeds. In addition, the high lipid content of the seed may hamper its preservation. To evaluate the effect of the maturation stage at harvesting on the physiological quality and chemical composition of the oil radish seeds stored under different conditions, the siliques were harvested at three stages, according to three colors: green, beige and brown. Seeds from different siliques harvesting stages were stored at ambient conditions and in a cold chamber under dry conditions $\left(10^{\circ} \mathrm{C}\right.$ and $\left.46 \% \mathrm{RH}\right)$ and evaluated as to their physiological and health quality and chemical composition before being stored and after 3, 6 and 9 months of storage. The siliques color is not the ideal indicator to define the oil radish seeds harvesting time due to the variation of the maturity and physiological quality of oil radish seeds within the siliques. The oil radish seeds storage in cold chamber preserves the physiological quality as assessed by the emergence test. There were no consistent changes in the centesimal composition of oil radish siliques harvested at different stages of maturation in relation to their color alteration.
\end{abstract}

Index terms: Raphanus sativus, storage, maturation.

\section{Colheita, beneficiamento e controle de qualidade de sementes de nabo forrageiro}

\begin{abstract}
RESUMO - A maturação das síliquas de nabo forrageiro ocorre de maneira desuniforme, o que dificulta a definição do momento ideal de colheita para produção de sementes de qualidade superior. Além disso, o alto conteúdo lipídico da semente pode dificultar sua conservação. Para avaliar o efeito do estádio de maturação na colheita sobre a qualidade fisiológica e a composição química de sementes de nabo forrageiro armazenadas sob diferentes condições, as síliquas foram colhidas em três estádios de maturação identificados pelas colorações, verde, bege e marrom. As sementes provenientes dos diferentes estádios de colheita das síliquas foram armazenadas em condições ambientais e câmara fria e seca $\left(10{ }^{\circ} \mathrm{C}\right.$ e $46 \%$ de UR) e avaliadas quanto à sua qualidade fisiológica, sanitária e composição química antes de armazenadas e aos 3, 6 e 9 meses de armazenamento. A cor das síliquas não é indicativo ideal para definição do momento de colheita das sementes de nabo forrageiro pela variação de maturidade e qualidade fisiológica das sementes dentro das síliquas. O armazenamento das sementes de nabo forrageiro em câmara fria preserva a qualidade fisiológica conforme avaliação do teste de emergência. Não foram observadas alterações consistentes na composição centesimal em síliquas de nabo forrageiro colhidas em diferentes estádios de maturação relacionados à sua alteração de cor.
\end{abstract}

Termos para indexação: Raphanus sativus, armazenamento, maturação.

\section{Introduction}

The knowledge of the process of seed maturation, as well as major physiological and chemical composition changes during storage of seeds constitute an important support in order to attain high quality standards in production and storage of oil radish seeds.

The determination of the physiological maturity of

${ }^{1}$ Submitted on 08/19/2013. Accepted for publication on 03/10/2014.

${ }^{2}$ Departamento de Agronomia, Universidade Federal dos Vales do Jequitinhonha e Mucuri , 39100-000 - Diamantina, MG, Brasil.

${ }^{3}$ Universidade Federal de Lavras, Caixa Postal, 3037, 37200-000 - Lavras, MG - Brasil. seeds based on the plants characteristics is complicated for this crop due to non-uniformity at the time of maturation of the siliques, which occurs in the same opening sequence of its inflorescence, a fact observed in most species of the Brassicaceae family. So, it becomes difficult to decide on the optimal timing of harvesting, to ensure maximum productivity and quality of seeds.

Many studies have shown that changes in the siliques

${ }^{4}$ Universidade Federal de São João Del-Rei, 36307-352 - São João DelRei, MG, Brasil.

Corresponding author:<nery.marcela@gmail.com> 
color may be an indicative of seed maturation, as observed in canola oil (Amaral et al., 2012). Concurrently, changes occur in chemical composition, which is reported for oilseed species such as canola, sunflower and safflower (Ullah and Bano, 2011).

After maturation and harvesting, the deterioration process begins and that can be faster or slower depending on storage conditions of the seeds. The storage capacity and vigor increase with the development and maturation processes, a fact already observed for sunflower seeds (Silva and Rossetto, 2012).

The objective of this research was to evaluate the effect of harvesting maturity stage on the physiological quality and chemical composition of oil radish seeds stored under different conditions.

\section{Materials and Methods}

The field of oil radish seed production was developed at Federal University of Lavras, Lavras-MG, Brazil. The oil radish CATI AL-1000 was sown from June to September 2007 in an experimental field, using $60 \mathrm{~cm}$ spacing between rows.

The crop was harvested when the plants contained $70 \%$ of their siliques in the color beige. The siliques were separated according to the predominant color, visually, in three stages of maturation, colored green, beige and brown. The siliques were dried in shade, threshed with sieves and processed in an air screen cleaner machine, using screens of $1.8 \mathrm{~mm} \mathrm{x} 3 / 4$ inches.

The seeds of different maturity stages were stored in multiwall paper bags for twelve months at ambient $\left(25^{\circ} \mathrm{C} \pm 3\right)$ and controlled conditions $\left(10^{\circ} \mathrm{C} \pm 3{ }^{\circ} \mathrm{C}\right.$ and relative humidity $46 \%$ ), monitored weekly. The oil radish seed quality was evaluated every three months, over a period of one year, by the following tests and determinations.

The seed moisture content was determined by the oven method at $105+3{ }^{\circ} \mathrm{C}$ for 24 hours (Brasil, 2009), with two replications of $10 \mathrm{~g}$ of seeds.

For germination test, the seeds were sown in sand at alternating temperature of $20{ }^{\circ} \mathrm{C}-30{ }^{\circ} \mathrm{C}$, with a 12 hours photoperiod. Four replications of 50 seeds were used and the results expressed as percentage of normal seedlings by day 4 (first count) and day 10 (germination). The germination speed index was calculated using the formula proposed by Maguire (1962), counting the number of seeds with radicle protrusion of $1 \mathrm{~mm}$ as a criterion for germination.

The emergence was made on soil + sand substrate in proportion 1:2 with moisture adjusted to $60 \%$ of retention capacity. After sowing of four replications of 50 seeds, the trays were kept at $20^{\circ} \mathrm{C}$. From the beginning of emergence, they were evaluated daily, computing the initial stand on the $3^{\text {rd }}$ day and the number of seedlings until stand stabilizes.
The emergence speed index was determined according to the formula proposed by Maguire (1962).

For the accelerated aging test, 200 seeds were maintained at $41{ }^{\circ} \mathrm{C}$ for 48 hours, according to AOSA (1983).

The blotter test was carried out on the seeds by the filter paper method or modified blotter test, with the use of 2.4-D (2.4-dichlorophenoxyacetic acid) at $10 \mathrm{mg} . \mathrm{dm}^{3}$ and freezing, using 200 seeds, divided into four replications of 50 seeds and placed on three sheets of filter paper imbibed in distilled water, and 2.4-D agar. Seven days after sowing, the presence of fungi on the seeds was assessed using a stereoscopic microscope.

To determine the chemical composition of oil radish seeds, $60 \mathrm{~g}$ of seeds were ground triturated in a mill (brand Tecnal ${ }^{\circledR}$ model TE613/1) and then refrigerated at $4{ }^{\circ} \mathrm{C}$. Three replications were used for all determinations of chemical composition. For ethereal extract, $2 \mathrm{~g}$ of sample were weighed into cartridge filter paper and a continuous extraction with refluxing was performed, in the presence of ethyl ether. After complete evaporation and recovery of the solvent, the residue was taken to an incubator at $65{ }^{\circ} \mathrm{C}$ for 24 hours, weighed and the results were expressed as a percentage (AOAC, 1990).

In the determination of crude protein (total nitrogen), samples were digested with potassium sulphate, copper sulphate and concentrated sulfuric acid, determining the total nitrogen content, by micro-Kjeldahl method (AOAC, 1990), by the factor 6.25 to calculate the crude protein content.

For crude fiber, the nonfat material was digested with acetic acid, trichloroacetic acid and nitric acid, and taken to the kiln's method at $105 \pm 3{ }^{\circ} \mathrm{C}$ for 24 hours. By the difference between the total weight and the weight of the empty crucible, the amount of crude fiber in the sample was expressed by the difference between the total weight and the weight of the empty crucible (Van der Kamer and Van Ginkel, 1952).

The total soluble sugars, reducing and no reducing, were extracted by the method of Lane-Enyon (AOAC, 1990) and determined by the technique of Somogy (1945), previously adapted by Nelson (1944).

In the determination of total tannins, $2 \mathrm{~g}$ of the samples were weighed into $25 \mathrm{~mL}$ Erlenmeyer flask, using as extractor, $50 \mathrm{~mL}$ of $80 \%$ methanol. The samples were heated on a metal plate at $100{ }^{\circ} \mathrm{C}$ for 15 minutes, and the bottles were sealed with a reflux lid, after filtered and finally quantified according to the method Follin-Denis, described by AOAC (1990).

The starch determination was carried out according to the methodology described by Somogy (1945), previously adapted by Nelson (1944).

A completely randomized design was used, in factorial scheme $3 \times 2 \times 5$ ( 3 stages of harvest, 2 storage conditions and 5 storage periods). The data were first tested for normality of 
residuals and homoscedasticity of variances. The data were submitted to analysis of variance and regression analysis and the means tested by the Scott-Knott test at 5\%. For the results regarding to seed health, only the incidence average of present microorganisms were performed.

\section{Results and Discussion}

According to the results obtained by the analysis of variance, it can be observed, as to seed quality, that the effect among tegument color, time and storage environment influenced on seedling emergence (Table 1). The interaction between time and storage environment influenced on the germination rate and on the emergence speed index. It can also be observed that the interaction between tegument color and storage time influenced on the first count and on the emergence speed index, while storage time interferes on the moisture and on the germination and the storage environment interferes on accelerated aging (Table 1).

For the chemical composition of the seeds, the interaction effect between tegument color, time and storage environment did not influence on determination of sugars and non-reducing sugars. For these variables it was observed only the interaction effect between tegument color $\mathrm{X}$ time and tegument color $\mathrm{X}$ storage environment and, even, time $\mathrm{X}$ storage environment for non-reducing sugars, as shown in Table 2.

Table 1. Analysis of variance observed seed moisture content (MC), germination (G), germination speed index (GSI), first count (FC), emergence (E), emergence speed index (ESI) and accelerated ageing (AA) on seed of oil radish with diferent tegument color and storage environment.

\begin{tabular}{lcccccccc}
\hline \multicolumn{1}{c}{ FV } & GL & MC & G & GSI & FC & E & ESI & AA \\
\hline Tegument color (TC) & 2 & 1.11 & 24.03 & $35.51^{*}$ & $1368.26^{* *}$ & $2378.23^{* *}$ & 10.30 & 193.08 \\
Time (T) & 4 & $6.07^{* *}$ & $528.28^{* *}$ & $1260.02^{* *}$ & $18713.97^{* *}$ & $10698.12^{* *}$ & $718.44^{* *}$ & $426.99^{* *}$ \\
Ambient (A) & 1 & 0.82 & 13.33 & 0.19 & 53.33 & 480.00 & 2.78 & $456.30^{*}$ \\
TC X T & 8 & 0.29 & 24.41 & 15.01 & $653.65^{* *}$ & 406.94 & $20.56^{* *}$ & 93.67 \\
TC X A & 2 & 0.27 & 21.43 & 17.54 & 196.76 & 6.30 & 9.37 & 80.63 \\
T X A & 4 & 0.57 & 17.92 & $23.33^{* *}$ & 286.83 & $641.25^{*}$ & $15.79^{*}$ & 154.94 \\
TC X T X A & 8 & 0.39 & 25.14 & 18.15 & 47.32 & $837.93^{* *}$ & 4.43 & 53.36 \\
Error & 90 & 0.32 & 16.73 & 9.16 & 137.86 & 219.87 & 6.38 & 80.75 \\
\hline \multicolumn{1}{c}{ CV (\%) } & & 7.45 & 4.34 & 9.97 & 21.21 & 27.85 & 25.72 & 9.91 \\
\hline
\end{tabular}

Table 2. Analysis of variance relative ethereal extract (EE), protein (P), Fiber (F), total soluble suggar (TSS), non-reducing suggar (NRS), suggar (S), reducing suggar (RS), and tanins (T) for determination of chemical composition on seed of oil radish with diferent tegument color and storage environment.

\begin{tabular}{lcccccrccc}
\hline \multicolumn{1}{c}{ FV } & GL & EE & \multicolumn{1}{c}{ P } & \multicolumn{1}{c}{ F } & \multicolumn{1}{c}{ TSS } & \multicolumn{1}{c}{ NRS } & \multicolumn{1}{c}{ S } & \multicolumn{1}{c}{ RS } & T \\
\hline Tegument color (TC) & 2 & $60.05^{* *}$ & $165.39^{* *}$ & $2.64^{* *}$ & $7.03^{* *}$ & $9.66^{* *}$ & $0.28^{* *}$ & $1.96^{* *}$ & $0.00^{* *}$ \\
Time (T) & 4 & $19.32^{* *}$ & $203.68^{* *}$ & $132.27^{* *}$ & $80.21^{* *}$ & $151.333^{* *}$ & $14.47^{* *}$ & $6.48^{* *}$ & $0.06^{* *}$ \\
Ambient (A) & 1 & 0.01 & 1.87 & $16.99^{* *}$ & $27.54^{* *}$ & $23.25^{* *}$ & $0.30^{* *}$ & $1.84^{* *}$ & $0.01^{* *}$ \\
TC X T & 8 & $4.34^{*}$ & $72.61^{* *}$ & $4.33^{* *}$ & $5.62^{* *}$ & $5.40^{* *}$ & $0.06^{* *}$ & $1.13^{* *}$ & $0.00^{* *}$ \\
TC X A & 2 & $10.46^{* *}$ & $26.30^{* *}$ & $1.34^{*}$ & $12.55^{* *}$ & $8.48^{* *}$ & $0.07^{*}$ & $0.82^{* *}$ & $0.03^{* *}$ \\
T X A & 4 & 0.84 & $3.38^{* *}$ & $18.93^{* *}$ & $6.31^{* *}$ & $5.07^{* *}$ & 0.03 & $0.29^{*}$ & $0.00^{*}$ \\
TC X T X A & 8 & $3.96^{*}$ & $10.36^{* *}$ & $0.75^{*}$ & $1.55^{* *}$ & $0.83^{* *}$ & 0.02 & 0.17 & $0.00^{* *}$ \\
Error & 60 & 1.60 & 0.47 & 0.32 & 0.34 & 0.29 & 0.02 & 0.10 & 0.00 \\
\hline \multicolumn{1}{c}{ CV (\%) } & & 4.02 & 2.25 & 5.82 & 8.04 & 9.87 & 8.83 & 7.36 & 4.67 \\
\hline
\end{tabular}

In processing, the seeds harvested from the green siliques were green or light brown and contained $43 \%$ of moisture content; from the beige and brown siliques, the predominant color was light brown, dark brown and reddish brown, with $11 \%$ and 9\% moisture content (Figure 1). Similar results were found in cabbage seeds, observing dehydration to $11 \%$ water content between seeds from green to purple pods (Freitas et al., 2007).

During storage of oil radish seeds in ambient temperature, the maximum and minimum temperatures varied from $33.2{ }^{\circ} \mathrm{C}$ in February to $13.0^{\circ} \mathrm{C}$ in May and August, while the air relative humidity ranged from $78 \%$ (January) to $55 \%$ (July). Despite the differences in temperature and 
relative humidity observed, this factor did not influence the reduction of the oil radish seeds quality (Figure 2).
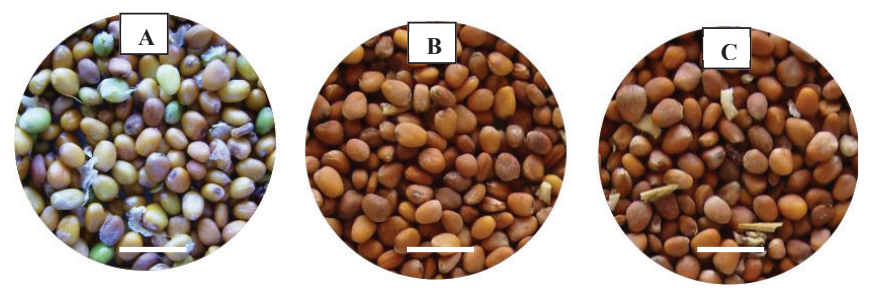

Figure 1. Visualization of oil radish seeds obtained from siliques at different harvesting stages, green (A), beige $(\mathrm{B})$ and brown $(\mathrm{C})$. $\mathrm{Bar}=1.0 \mathrm{~cm}$.

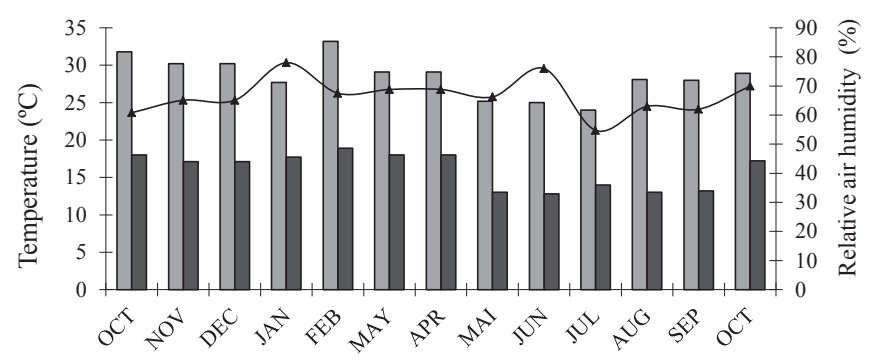

Months (2007 to 2008)

Figure 2. Monthly average temperature and relative air humidity recorded on the storage period of oil radish seeds in ambient conditions.

After processing, the seeds were stored at $6 \%$ moisture. Regardless of degree of maturation and storage conditions of the oil radish seeds, moisture content varied during the storage. An increase in the moisture content of $6 \%$ to $7 \%$ it was observed at 3 months and $8 \%$ at 6,9 and 12 months of storage (Figure 3). This variation in moisture content of seeds during storage is common, because the seeds tend to the hygroscopic equilibrium as a function of temperature and relative humidity (Marini et al., 2007). According to Caetano et al. (2012), the factor that most influences the hygroscopic equilibrium of stored seeds is the chemical composition, as observed for oilseed equilibrium with low levels of humidity, such as canola that is stored with $9 \%$ (Luz et al., 2012) and the castor bean that is stored with 6\% (Fanan et al., 2009).

The stage of harvest and storage period influenced the first count of seed germination (Figure 4A). A decrease for all stages of harvesting siliques, was observed starting at 6 months, being more accentuated for seeds harvested from the green siliques, followed by beige and brown siliques.

The reduction in seed vigor in green siliques can be explained by the chlorophyll effects or photo oxidation, reacting with intermediates of lipid peroxidation and peroxide. Lipid peroxidation is one of the causes of seed deterioration and is correlated with the decline of seed vigor (Oliveira et al., 2012).

In relation to germination, the storage period had a positive influence on seed quality, with increases up to $12 \%$ in a 12 month period (Figure 4B). Probably the lower germination at the beginning of storage can be attributed to the presence of dormancy and the incidence of fungi, with the time of storage, these factors have been reduced or even eliminated. Decrease of dormancy during storage has also been observed in B. napus (Ortegón Morales et al., 2006).

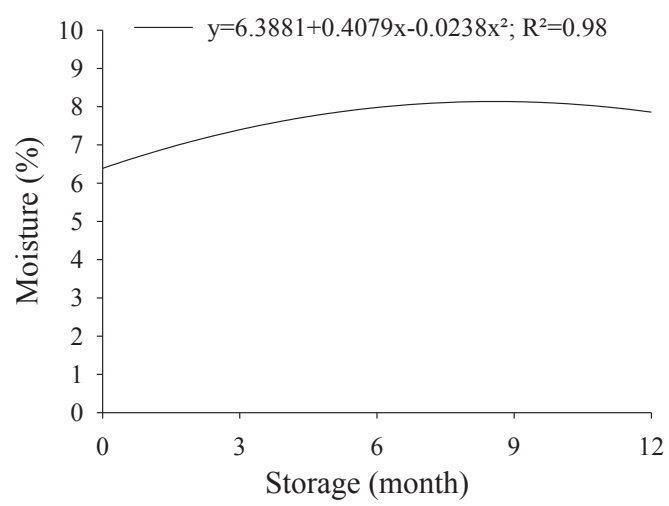

Figure 3. Moisture contents of oil radish seeds during storage in ambient condition.
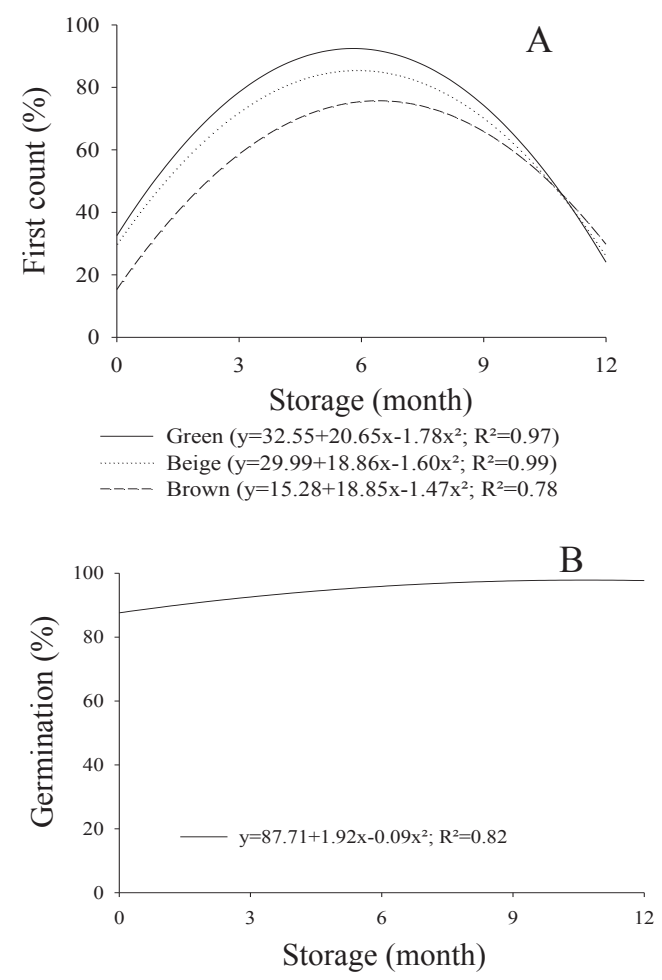

Figure 4. Means values of the first count (A) and germination percentage (B) of oil radish seeds during storage in ambient conditions and cold chamber. 
Regarding the vigor of the seeds analyzed by germination speed index, there were differences between seeds stored at ambient conditions and cold chamber (Figure 5). After six months, the decrease in the germination speed index was more accentuated when seeds remained stored in ambient conditions.

The interaction between storage period and the harvesting stage influenced the vigor measured by initial stand. It is observed that in seeds from green and beige siliques the reducing of vigor was more pronounced when compared with those from brown siliques (Figure 6).

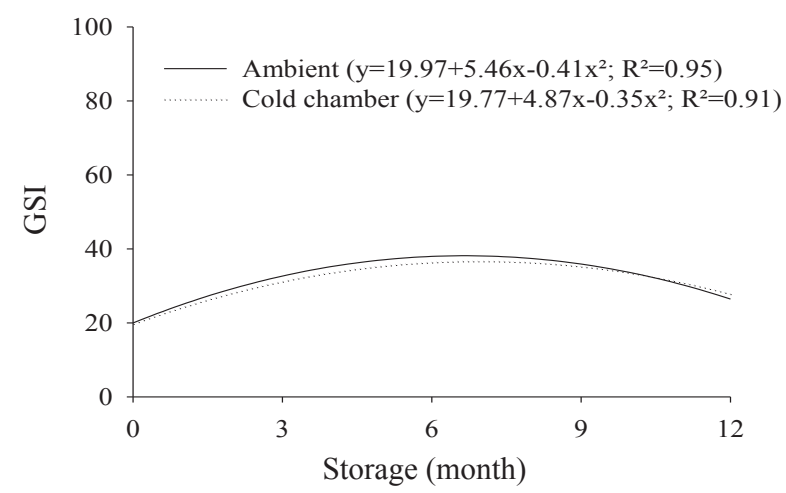

Figure 5. Means values of germination speed index (GSI) of oil radish seeds at different harvesting stages and storage period.

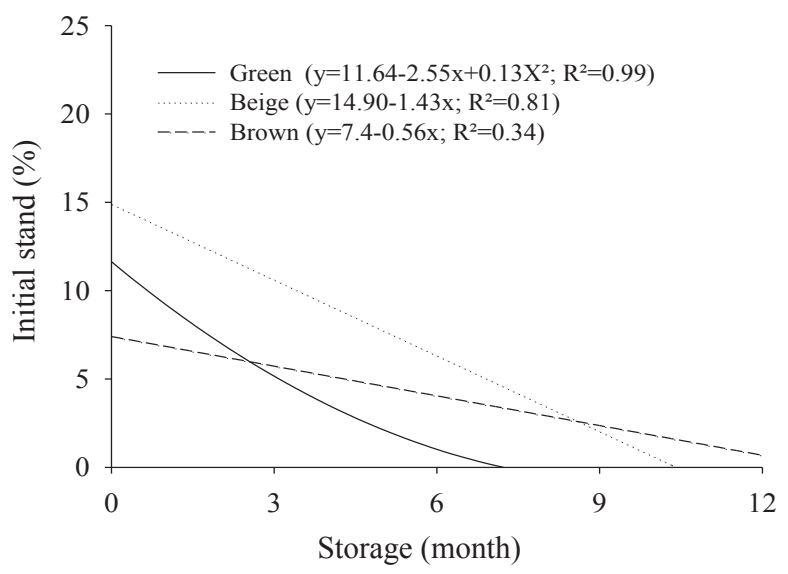

Figure 6. Means values of the initial stand (\%) of oil radish seeds, obtained at different harvesting stages and storage period.

For the emergence results, the effect of factors: harvesting stage, storage conditions and storage period was observed (Figures 7A and B). In ambient conditions as much as in cold chamber, decreases were observed in vigor for seeds harvested in different siliques, however, for seeds from green siliques the decrease in vigor was more pronounced when stored at ambient conditions (Figure 7A) when compared with those stored in cold storage (Figure 7B).
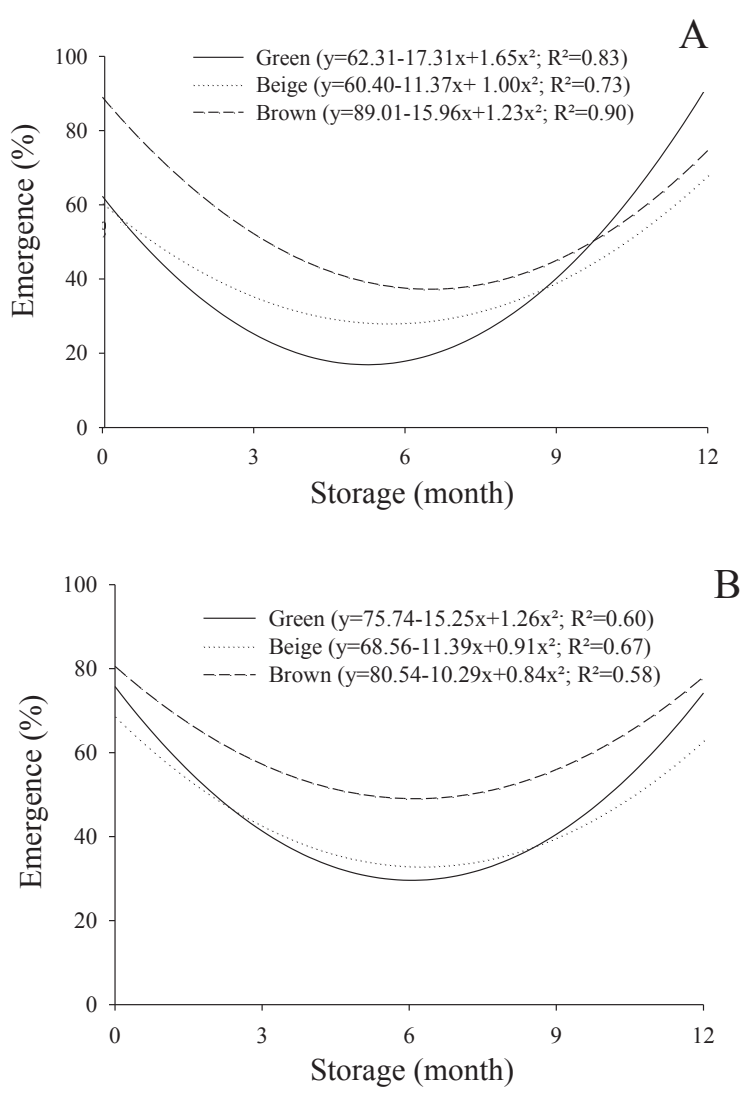

Figure 7. Means values of emergence of oil radish seeds at different harvesting stages, storage period and ambient storage conditions (A) and cold chamber (B).

The stage of harvest and storage conditions had a negative influence on the emergency speed index, resulting in decreases in vigor, regardless of the stage of harvest of the siliques (Figures 8A and B). For seeds stored in cold chamber (Figure 8B), the reduction of the emergence speed index emergency speed of was less pronounced when compared to those kept at ambient conditions (Figure 8A). This reduction in vigor can be attributed to the high oil content, because it is known that oilseeds have low storage capacity, which is also observed for canola seeds (Rossetto and Nakagawa, 2000).

When seeds were submitted to artificial aging, the period and storage conditions affected seed quality (Figure 9, Table 3). The decline of seed vigor can be checked from the sixth month (Figure 9) and ambient conditions affected negatively when compared to those stored in cold chamber (Table 3).

It was found that fungi associated in a higher incidence with the oil radish seeds were Cladosporium sp. Alternaria sp. and Fusarium sp. and in a lower incidence, Aspergillus flavus, Epicocum sp., Phoma sp. Isariopsis sp., Penicillium sp., 
Phoma sp., Mucor sp., Nigrospora sp. (Table 4). In a general way, the seeds from green siliques had a higher incidence of fungi when compared to the ones from other treatments. It was also found that for Cladosporium spp. and Alternaria spp.
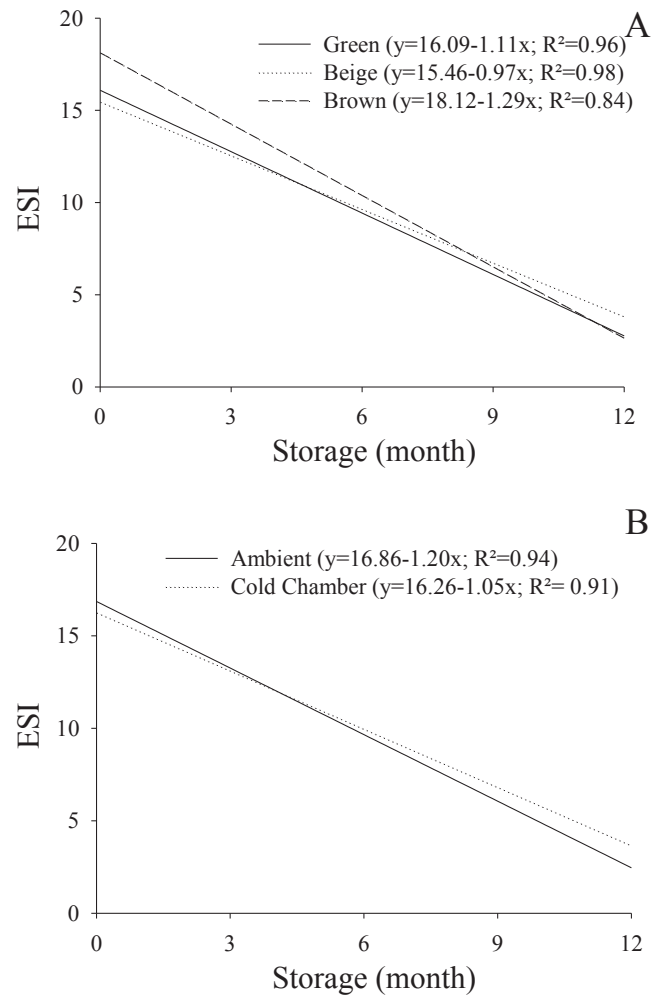

Figure 8. Means values of emergence speed index (ESI) of oil radish seeds at different harvesting stages (A) and storage period and ambient conditions and cold chamber (B).

By the analysis of previous tests, it was observed that divergent results on the physiological quality of oil radish seeds hindered a definition of the ideal harvest stage based on the siliques color. This may have occurred by the difference of seed maturation within siliques, which was verified for canola (Amaral et al., 2012). Moreover, with the cutting of plants, abrupt changes occurred in the color of the siliques of oil radish, which may have led to harvest stage classification errors.

In chemical composition of seeds, the average moisture of ground samples of oil radish obtained from the seeds from green siliques $(7 \%)$ was superior to those obtained from other siliques, beige and brown (6\%). In the ambient storage condition, the moisture content varied between $5 \%$ to $7 \%$.

The content of the ethereal extract it was influenced by maturation of the siliques, the condition and storage period (Figures $10 \mathrm{~A}$ and B). Seeds from brown and beige siliques had a reduction in the concentration during the storage period there was a reduction according to the seeds kept stored at ambient conditions and in a cold chamber. In the cold chamber condition the incidence of Fusarium sp. increased at 3 months and remained stable until 12 months of storage.

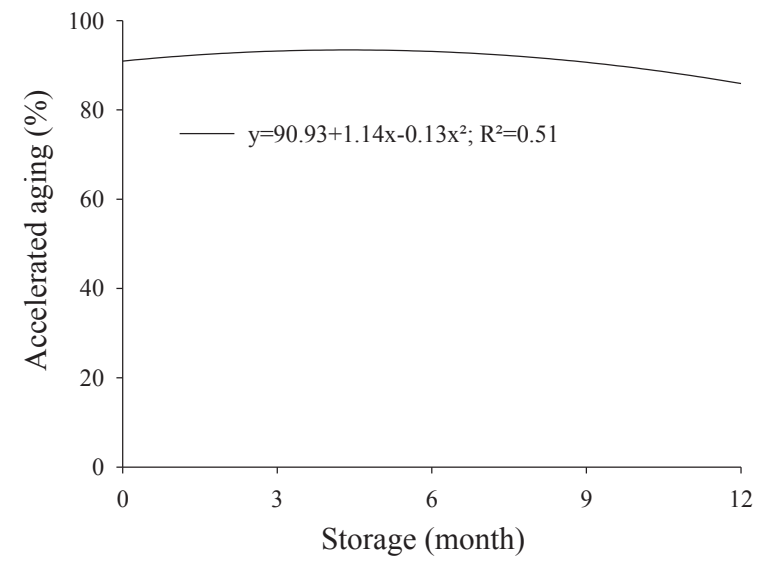

Figure 9. Results of the accelerated aging test (\%) of oil radish seeds during storage in ambient storage conditions and cold chamber.

Table 3. Means values of percentage of normal seedlings obtained after accelerated aging of seeds.

\begin{tabular}{cc}
\hline \multirow{2}{*}{ Storage Locations } & Accelerated aging \\
\cline { 2 - 2 } & $-------------(\%)$---------- \\
\hline Ambient & $99 \mathrm{~b}$ \\
Cold chamber & $93 \mathrm{a}$ \\
\hline CV $(\%)$ & 9.91 \\
\hline
\end{tabular}

Means followed by same letter in the column do not differ (Scott-Knott and F tests, $p>0.05$ ).

at ambient conditions, while those obtained from green siliques increased the content of ethereal extract (Figure 10 A). For seeds stored in cold chamber, only those from the beige siliques were influenced, reducing the ethereal extract from the sixth month of storage (Figure $10 \mathrm{~B}$ ). For Brassica napus, variations in the oil content were also observed according to the environment in which the seeds were produced (Moghadam et al., 2011).

When seeds were stored under different conditions, there was an increase in crude protein content (Figures $11 \mathrm{~A}$ and B). In the seeds stored at ambient conditions, it was observed a higher content in the seeds from brown siliques, followed by beige and green (Figure $11 \mathrm{~A}$ ). When these were stored in cold chamber, the seeds from green siliques had higher levels, and then the brown and beige ones (Figure $11 \mathrm{~B}$ ). These data are consistent with the report about the inverse proportionality between the protein and oil content in seeds (Santos et al., 2010). 
Table 4. Average incidence of fungi in the oil radish seeds at different stages of siliques harvesting, green (G), beige (B) and brown $(\mathrm{Br})$, condition and storage period.

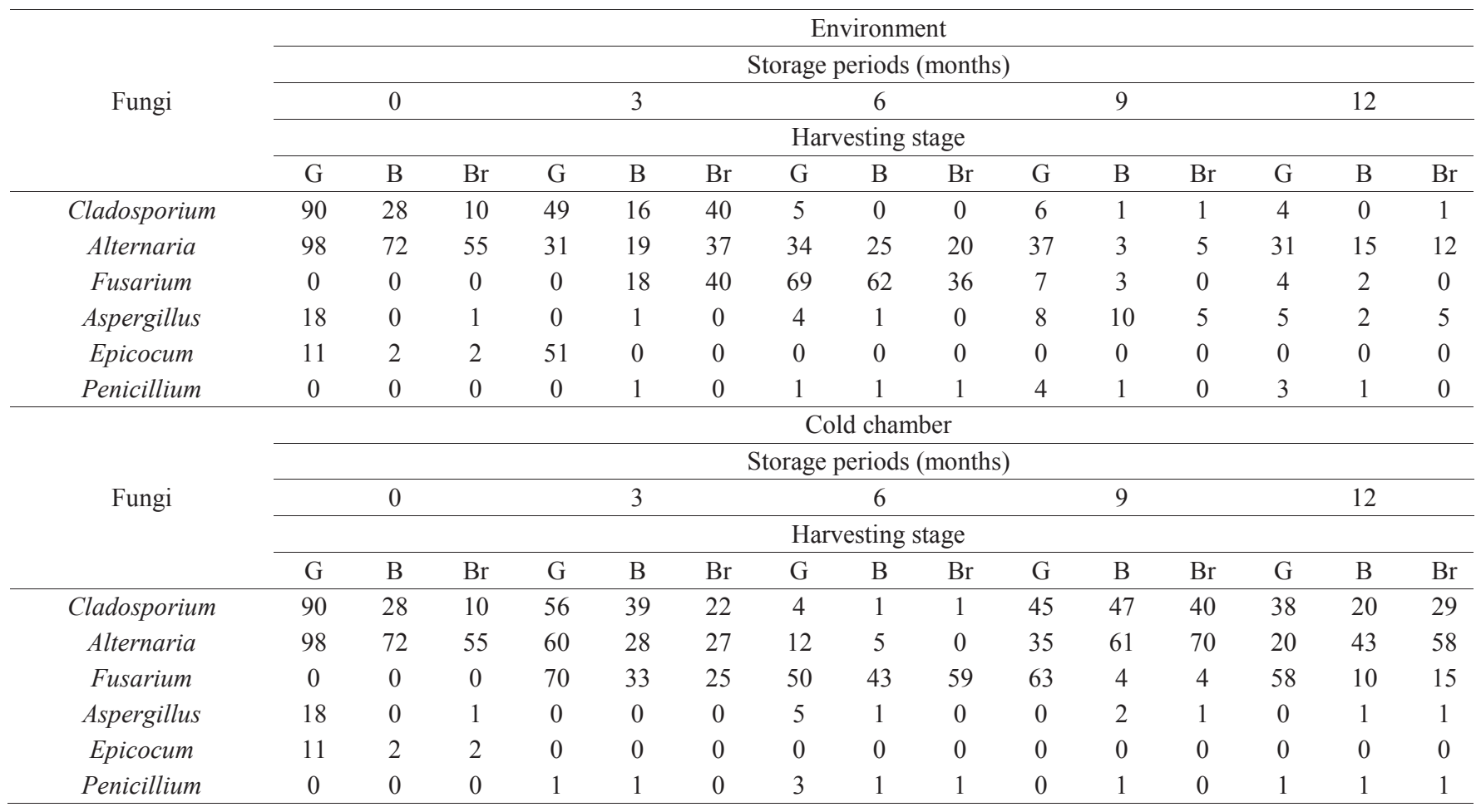
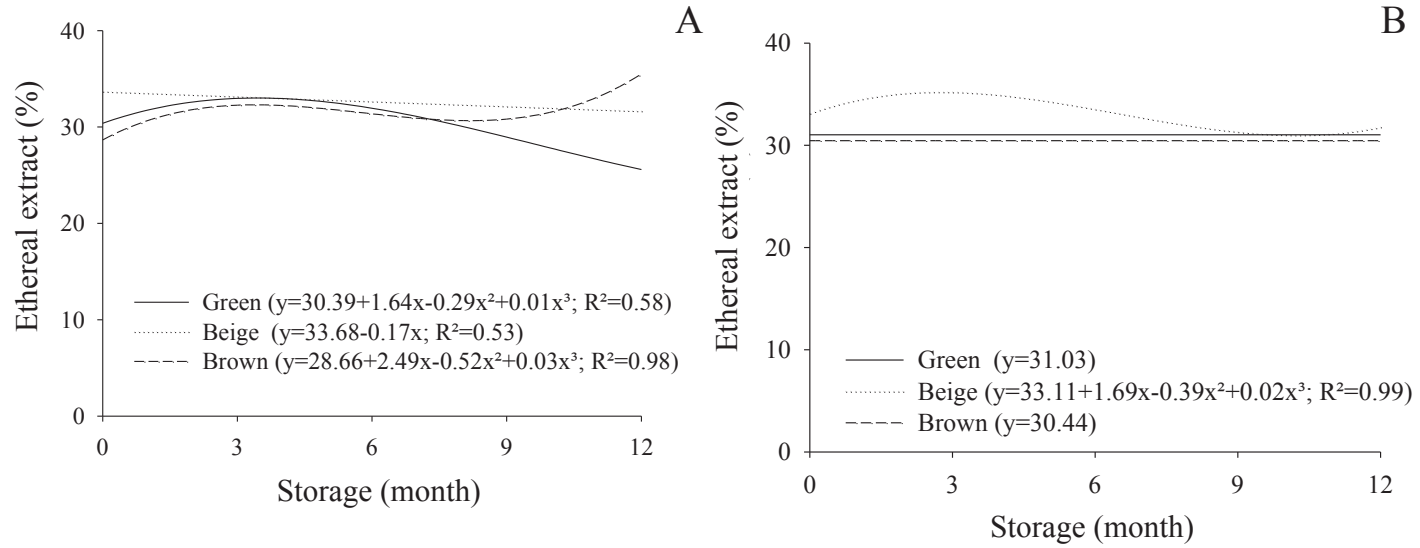

Figure 10. Mean percentage of ethereal extract of oil radish seeds harvested at different stages of the siliques and stored at ambient temperature (A) and cold chamber (B).

Another constituent found in the oil radish seeds are the fibers, including cellulose, hemicellulose and lignin, which are responsible for cellular structure of plants (Souza et al., 2009). The storage period promoted progressive reductions in the amounts of crude fiber, although variations occur between siliques maturation, condition, and time of storage (Figures $12 \mathrm{~A}$ and B). Probably, this reducing on the percentage of fibers is due to the process of seeds deterioration and membranes degradation.
The levels of total and non-reducing sugars (sucrose) increased during the maturation of the siliques, with a higher percentage for seeds from beige and brown siliques, followed by green ones. Sucrose is the most abundant soluble sugar in mature seeds and used by oilseeds in the synthesis of triglycerides and proteins, while reducing sugars such as glucose and fructose, are virtually absent (Jose et al., 2006).

During storage, the different conditions, the period and the stage of maturation of siliques influenced the content of total 
soluble sugars (Figures $13 \mathrm{~A}$ and B). When seeds were stored at ambient condition, occurred small variations in total soluble sugars of seeds from the beige and brown siliques, while for the seeds from green siliques there was reduction during storage
(Figure 13). For seeds stored in cold chamber, there was a progressive reduction of total soluble sugars in different stages of maturation of the siliques (Figure $13 \mathrm{~B}$ ). A similar behavior was observed in non-reducing sugar content (Figures 14 A and B).
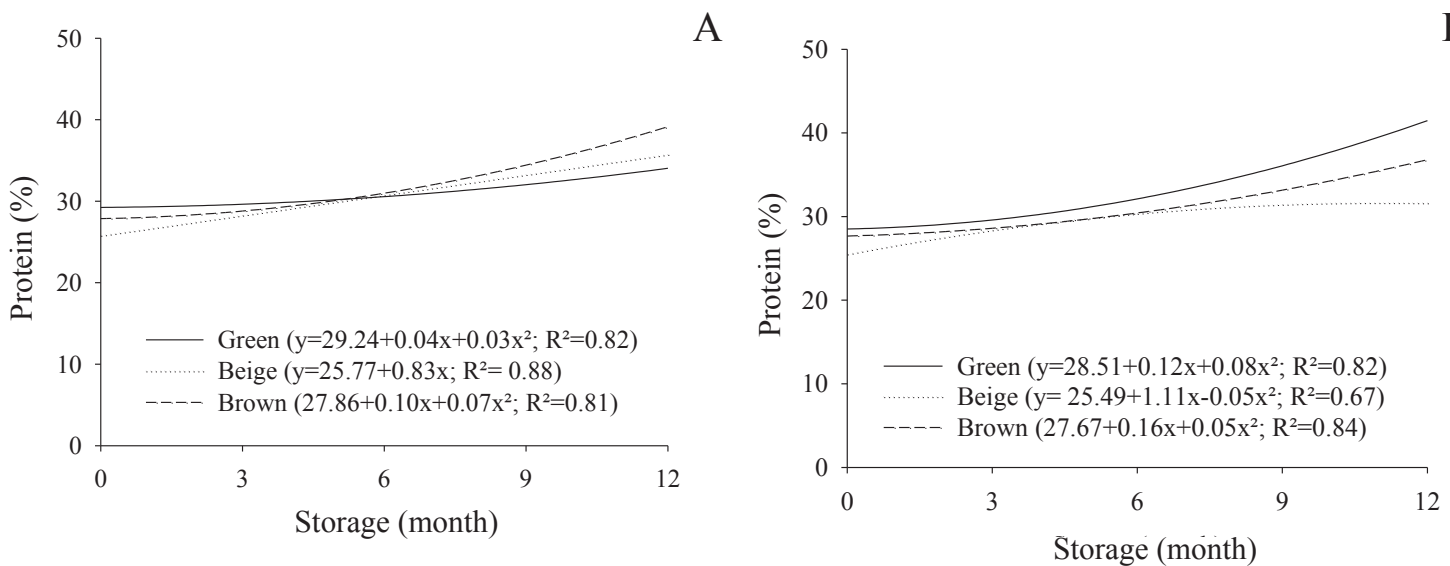

B

Figure 11. Mean percentage of total proteins of oil radish seeds, harvested at different stages of the siliques and stored at ambient temperature (A) and cold chamber (B).
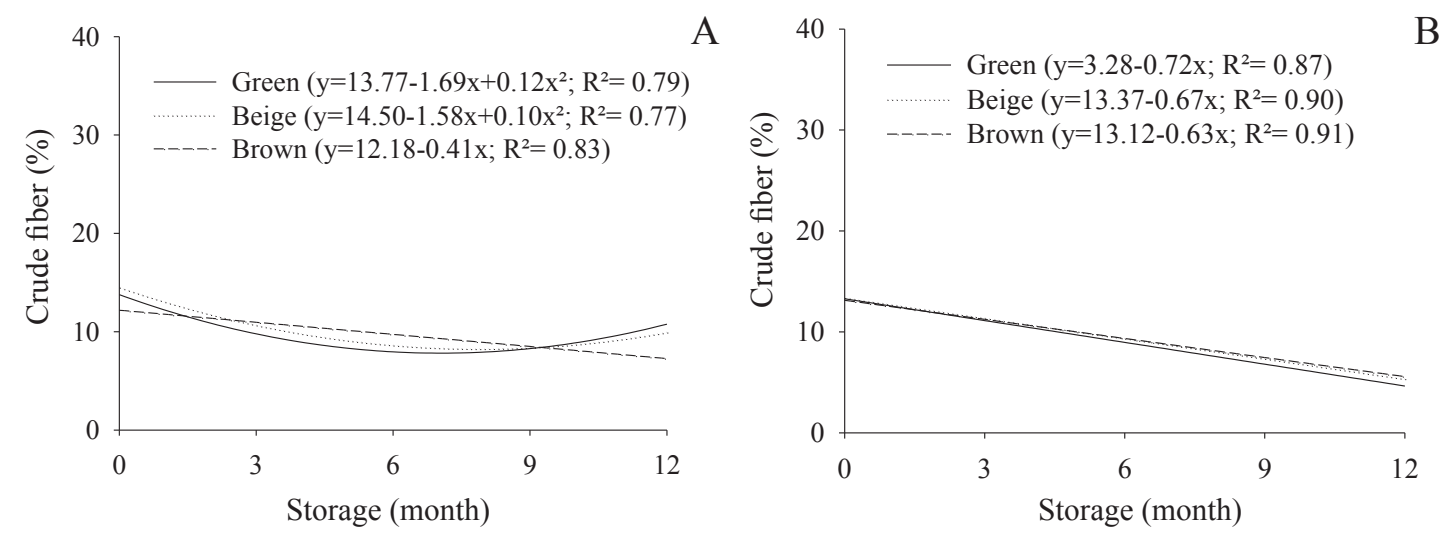

Figure 12. Mean percentage of crude fiber of oil radish seeds, harvested at different stages of the siliques and stored at ambient temperature (A) and cold chamber (B).
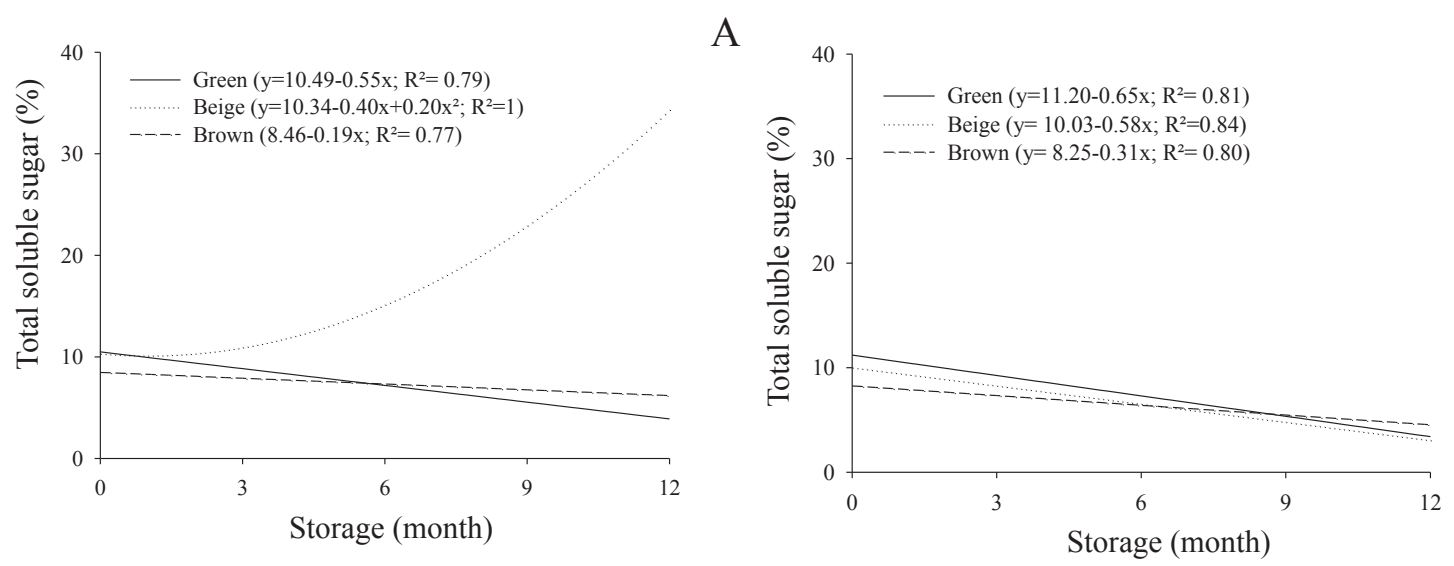

Figure 13. Mean percentage of total soluble sugars of oil radish seeds, harvested at different stages of the siliques and stored at ambient temperature (A) and cold chamber (B). 

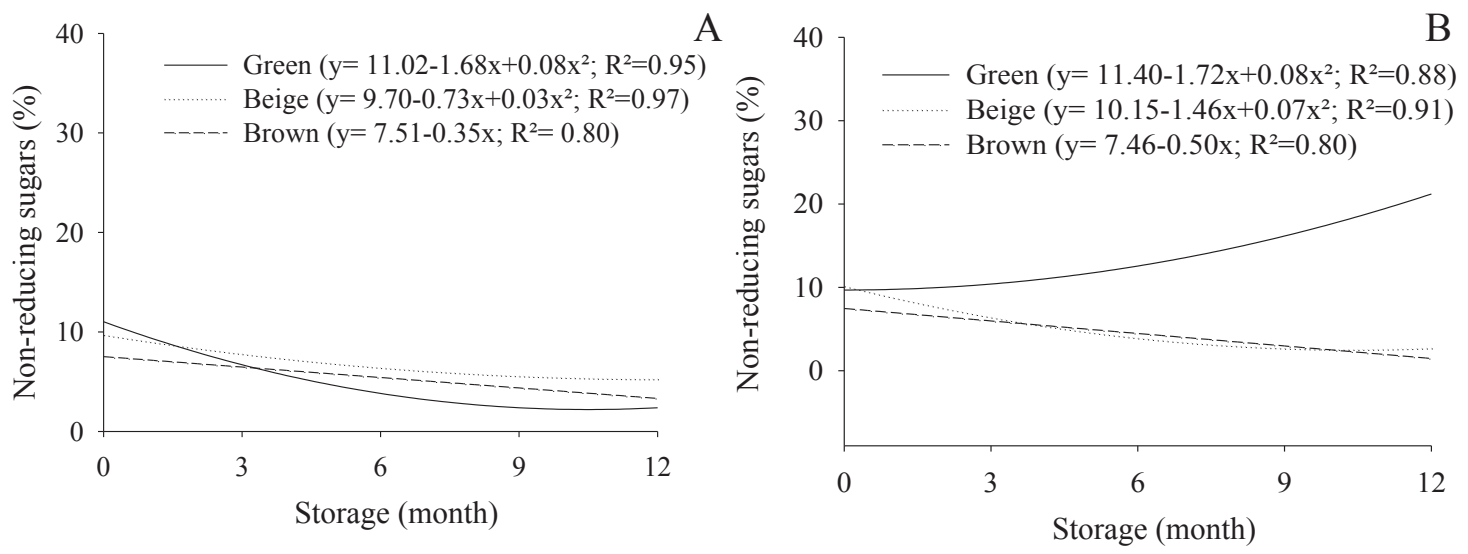

Figure 14. Mean percentage of non-reducing sugars of oil radish seeds, harvested at different stages of the siliques and stored at ambient temperature (A) and cold chamber (B).

The reduction in seedling vigor, due to aging of the seeds, is associated with decrease in soluble carbohydrates content, which are included the total soluble sugars and nonreducing (Eichelberger et al., 2002). Probably, the soluble carbohydrates in seeds of oil radish influenced the seedling vigor, reducing the speed of germination and emergence.

In relation to starch and reducing sugars, there was no significant effect on the seeds obtained from the different

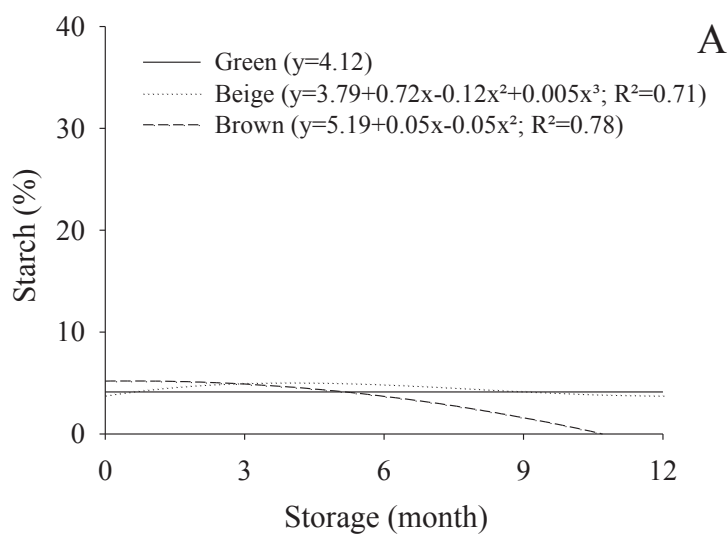

Figure 15. Mean percentage of starch (A) and reducing sugars storage.

Probably, the reduction in starch content in the seeds during the storage period is due to the higher activity of amylase cleaving the carbohydrate in lower sugars for use as respiratory substrate. The presence of high amounts of reducing sugars can cause chemical changes in proteins (Murthy and Sun, 2000) and DNA, through Amadori and Maillard reactions, which has a correlation with lipid peroxidation, accelerating the process of deterioration in seeds (Murthy and Sun, 2000). siliques. According to Bewley and Black (1994), during the development of oilseeds there is an accumulation of starch, which is then mobilized to triglyceride synthesis. Throughout the storage, it could be observed that there was a reduction of starch content in seeds from beige and brown siliques (Figure $15 \mathrm{~A})$. As for the reducing sugars, their amount was increased during the storage for all stages of maturation of the siliques (Figure 15 B).

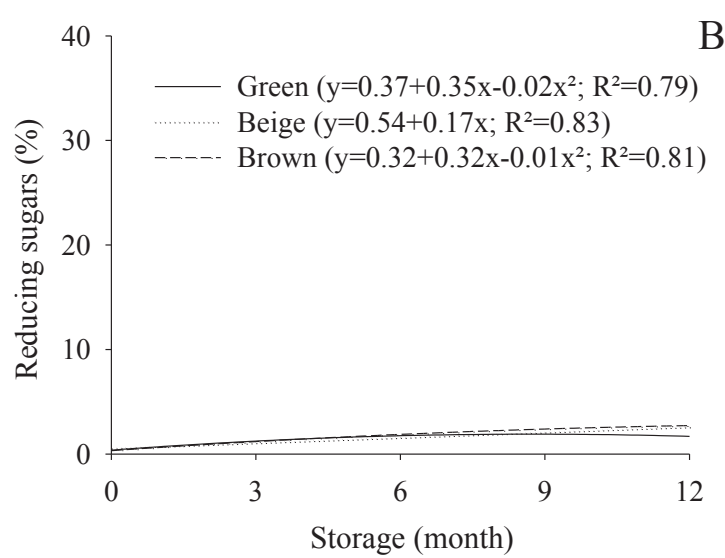

(B) of oil radish seeds at different harvesting stages during

In the content of tannins, values lower than $1 \%$ were observed, however, seeds from beige siliques contained higher percentage than the others. When submitted to different storage conditions, the tannin content was changed, with larger increases at 12 months in seeds from green siliques, with oscillations for the beige siliques and smaller additions to the brown siliques for storage at ambient conditions (Figure 16 A). In cold chamber condition, the behavior was different, with a largest increase in the levels of tannins for the seeds 
from the beige and brown siliques and less to green siliques (Figure $16 \mathrm{~B}$ ).
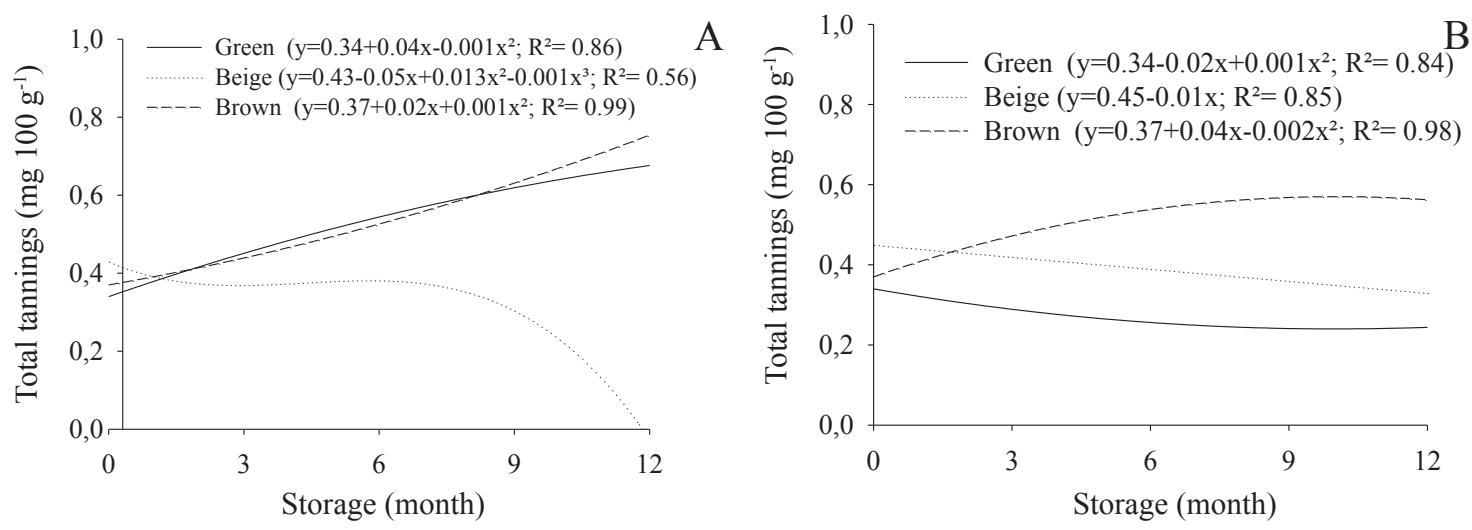

Figure 16. Means values of total tannins in oil radish seeds at different harvesting stages of the siliques at ambient condition (A) and cold chamber (B) during storage.

\section{Conclusions}

The color of the siliques is not an appropriate indicative for ideal harvest time of the oil radish seeds due to the variation of maturity and physiological quality of seeds within the siliques.

The storage of oil radish seeds in cold chamber favors the emergence of seedlings.

There were not observed consistent changes in the centesimal composition of oil radish siliques harvested at different stages of maturation related to their color alteration.

\section{References}

AMARAL, A. D.; MEDEIROS, S. L. P.; MENEZES, N. L.; LUZ, G. L.; PIVOTO, D.; BIALOZOR, A. Qualidade de sementes de canola classificadas por densidade. Revista Brasileira de Sementes, v.34, n.2, p.302-309, 2012. http://www.scielo.br/ scielo.php?script=sci arttext\&pid=S010131222012000200016\&lng=en\&tlng=pt. 10.1590/S0101-31222012000200016

AOAC. Association of Official Analytical Chemists - Methods of the association of official analitical chemists. 15. ed. Virginia: AOAC, 1990, $1230 \mathrm{p}$.

AOSA. Association of Official Seed Analysts. Seed vigor testing handbook. Lincoln:AOSA, 1983,93p. (Contribution 32).

BEWLEY, J. D., BLACK, M. Seeds: physiology of development and germination. New York: Plenum Press, 1994, 445p.

BRASIL. Ministério da Agricultura, Pecuária e Abastecimento. Regras para análise de sementes. Ministério da Agricultura, Pecuária e Abastecimento. Secretaria de Defesa Agropecuária. Brasília: MAPA/ACS, 2009. 395p. http:// www.bs.cca.ufsc.br/publicacoes/regras\%20analise\%20sementes. pdf.

CAETANO, G.S.; SOUSA, K.A.; RESENDE, O.; SALES, J.F.; COSTA, L.M. Higroscopicidade de sementes de caju-de-árvore-do-cerrado. Pesquisa Agropecuária Tropical,v.42,n.4,p.437-445,2012.http://www.scielo.br/scielo. php?script=sci_arttext\&pid=S198340632012000400012\&lng=en\&nrm=iso
EICHELBERGER, L.; MAIA, M. S.; PESKE, S. T.; MORAES, D. M. Composição química de sementes de azevém em resposta ao retardamento da secagem e ao armazenamento. Pesquisa Agropecuária Brasileira, v.37, n.5, p.639-701, 2002. http://www.scielo.br/pdf/pab/v37n5/9539.

FANAN, S.; MEDINA, P. F.; CAMARGO, M. B. P.; RAMOS, N. P. Influência da colheita e do armazenamento na qualidade fisiológica de sementes de mamona. Revista Brasileira de Sementes, v.31, n.1, p.150-159, 2009. http://www.scielo.br/pdf/rbs/v31n1/a17v31n1.pdf

FREITAS, R. A.; NASCIMENTO, W. M.; COIMBRA, K. G. Maturation and seed quality of summer cabbage seeds under tropical conditions. Horticultura Brasileira, v.25, n.4, p.586-589, 2007. http://www.scielo.br/ scielo.php?pid=S0102-05362007000400018\&script $=$ sci arttext

JOSE, S. C. B. R.; VON PINHO, E. V. R.; DIAS, M. A. G. S. Açúcares e tolerância à alta temperatura de secagem em sementes de milho. Revista Brasileira de Sementes, v. 28, n. 2, p. 60-68, 2006. http://www.scielo.br/scielo. php?script=sci_arttext\&pid=S0101-31222006000200008\&lng=en\&nrm=iso

LUZ, G.L.; MEDEIROS, S. L. P.; TOMM, G. O.; BIALOZOR, A.; AMARAL, A. D.; PIVOTO, D. Temperatura base inferior e ciclo de híbridos de canola. Ciência Rural, v.42, n.9, p.1549-1555. 2012. http://www.scielo.br/scielo. php? script $=$ sci_arttext\&pid=S0103-84782012000900006\&lng=en\&nrm=iso

MAGUIRE, J. D. Speed of germination-aid in selection and evaluation for seedling emergence and vigor. Crop Science, v.2, p.176-177, 1962. https:// dl.sciencesocieties.org/publications/cs/pdfs/2/2/CS0020020176

MARINI, L. J.; GUTKOSKI, L. C.; ELIAS, M. C.; SANTIN, J. A. Quality of oat grains under intermittent drying at high temperatures. Ciência Rural, v.37, n.5, p.1268-1273, 2007. http://www.scielo.br/scielo.php?pid=S0103$84782007000500008 \&$ script $=$ sci arttext

MOGHADAM, H. R. T.; ZAHEDI, H.; GHOOSHCHI, F. Oil quality of canola cultivars in response to water stress and super absorbent polymer application. Pesquisa Agropecuária Tropical, v.41, n.4, p.579-586, 2011. http://www. scielo.br/scielo.php?script=sci arttext\&pid=S1983-40632011000400007\&lng $=$ en\&nrm=iso

MURTHY, U. M. N.; SUN, W. Q. Protein modification by Amadori and Maillard reactions during seed storage: roles of sugar hydrolysis and lipid peroxidation. Journal of Experimental Botany, v.51, n. 348, p. 1221-1228, 2000. http://jxb.oxfordjournals.org/content/51/348/1221.full 
NELSON, N. A. Photometric adaptation of somogy method for the determination of glucose. Journal of Biological Chemists, v.153, n.2, p. 375384, 1944. http://www.jbc.org/content/153/2/375.full.pdf

OLIVEIRA, J. P. B.; ALEXANDRE, R. S.; NEGREIROS, J. R. S.; LOPES, J. C.; BRUCHNER, C. H. Lipid peroxidation and seed emergency in progenies of the yellow passion fruit plant. Revista Brasileira de Fruticultura, v.34, n.3, p.711-718, 2012. http://www.scielo.br/scielo.php?script=sci_ arttext\&pid=S0100-29452012000300009\&lng=en\&nrm=iso

ORTEGON MORALES, A. S.; DIAZ FRANCO, A.; GONZALEZ QUINTERO, J.; GARZA CANO, I. La temperatura en la etapa reproductiva del cultivo de canola (Brassica napus). Agricultura Técnica en México, v.32, n.3, p.259-265, 2006. http://www.scielo.org.mx/scielo.php?script=sci_ arttext\&pid=S0568-25172006000300002\&lng=es\&nrm=iso

ROSSETTO, C. A. V.; NAKAGAWA, J. Canola (Brassica napus L.) var. oleifera Metzg. Seed quality affected by the testa coloration, during storage. Revista Brasileira de Sementes, v.22, n.1, p.3137. 2000. http://www.cabdirect.org/abstracts/20023020332. html;jsessionid=B025A7401F5AD0E82515FBA71B05DB0A

SANTOS, E. L.; PIPOLO, A. E.; FARIA, R. T.; PRETE, C. E. C. Influence of genotype on protein and oil concentration of soybean seeds.Brazilian Archives of Biology and Technology, v.53, n.4, p.793-799, 2010. http://www.scielo.br/scielo. php?script=sci_arttext\&pid=S1516-89132010000400007\&lng=en\&nrm=iso>
SILVA, L. F.; ROSSETTO, C. A. V. Potencial fisiológico de sementes de girassol influenciado pelo umedecimento artificial. Ciência Rural, v.42, n. 7, p. 1161-1167, 2012. http://www.scielo.br/scielo.php?script=sci_ arttext\&pid=S0103-84782012000700004\&lng=en\&nrm=iso

SOMOGY, M. A. New regent for the determination of sugars. The Journal of Biological Chemistry, v. 160, n. 2, p. 601-668, 1945. http://www.jbc.org/ content/160/1/61.full.pdf

SOUZA, A. D. V.; FAVARO, S. P.; ITAVO, L. C. V.; ROSCOE, R. Caracterização química de sementes e tortas de pinhão-manso, naboforrageiro e crambe. Pesquisa Agropecuária Brasileira, v. 44, n. 10, p. 13281335, 2009. http://www.scielo.br/scielo.php?script=sci_arttext\&pid=S0100204X2009001000017\&lng=en\&nrm=iso

ULLAH, F.; BANO, A. Effect of plant growth regulators on oil yield and biodiesel production of safflower (Carthamus tinctorius L.). Brazilian Journal of Plant Physiology, v. 23, n. 1, p. 27-31, 2011.http://www.scielo.br/scielo. php?script=sci_arttext\&pid=S167704202011000100005\&lng=en\&nrm=iso

VAN DER KAMER, S. B.; VAN GINKEL, L. Rapid determination of crude fiber in cereals. Cereal Chemistry, v. 19, p. 239-251, 1952. 